\title{
THE IMPORTANCE OF REGIONS IN GEOGRAPHICAL RESEARCH
}

\author{
Snežana Vujadinovič ${ }^{*}{ }^{*}$ Dejan Šabić ${ }^{*}$ \\ "University of Belgrade - Faculty of Geography, Belgrade
}

\begin{abstract}
The history of the 20th century was marked by the evolution of the concept of a region that has undergone various formulations, as well as rejections. Different authors define the region as a natural, human, historical, cultural, as well as economic reality. The notion of the region is multifaceted because the region makes a complex interconnection between different geographical, economic, cultural, political and other factors. In certain approaches, the region is viewed as a concrete fact, in other approaches, the region is only a theoretical fact, namely the creativity of the human spirit. Regions are often studied as a product of the interaction of individuals or social groups in different economic, political, and cultural contexts. Regionalization establishes the regions as administrative and political units within the national state. Consequently, regionalization implies decentralization, as it transfers the part of the authorities from the national to the regional level. The forms of the regional structure depend on the historical, geographical, political, and cultural specifics of the territory. From the aspect of the region, regionalization contributes to its affirmation and preservation of regional specifics, primarily cultural, but also of various interests - social, economic, political, etc. From the aspect of the state as a superior entity, regionalization contributes to the achievement of a balanced development of the region and more efficient connection of state authorities to the local one. These two aspects of regionalization should be compatible, but in practice this does not usually come about.
\end{abstract}

Key words: region, regional geography, traditional and modern concept, spatial units.

${ }^{1}$ Corresponding author: S. Vujadinović, University of Belgrade - Faculty of Geography, Studentski trg 3/III, 11,000 Belgrade, Serbia; e-mail: vujadinovicnezana@gmail.com 


\section{Introduction}

Problems of regional differences, unequal territorial distribution of household income, and economic development opportunities are important theoretical and practical issues in all countries in the world. The overthrowing or re-composing of Europe's political space since the 1990s has led to the rise of economic regions - new territorial units in the political arena of Europe. The scientific problems of our research are related to the changes that have arisen under the influence of natural, social, and economic factors. Solving scientific problems in our article involves a complex definition of causality between the regions, territorial capital and regionalization. The task of the article is to identify the causes that lead to regional imbalances, as well as to define the direction of balanced regional development. The mentioned scientific problems are part of a complex subject of study, the aim of which is to identify, define and monitor the transformation of the region in order to perceive the future development. The secondary goal of the article is to point out the social and scientific importance of regional and development policy, as well as numerous problems and challenges in practice when it comes to the use of local resources and the strengthening of competitiveness.

\section{Previous research}

According to the concept of traditional regional geography, the region is a limited spatial system and the expression of organizational unity (Allen et al., 1998; Amin, 2004; Bristow, 2010; Castells, 1996; Cooke and Morgan, 1994; Gilbert, 1988). The region represents the product of the territorial differentiation of the world. The connection between spatial and social dynamics is within the region, which, in analysis of traditional regional geography, coincides with territorial units (Keating, 1998; Levis and Wigen, 1997; MacLeod, 2001; Meijers and Romein, 2003). The first definition of the term region was given by Herbertson, in an article published in 1905. According to Herbertson, the natural region represents the unity of configuration, climate, as well as vegetation. At that time, which was marked by natural determinism, the region was a reflection of physical reality. Paul Vidal de La Blache proposed the concept of a geographic region that represents a different combination of natural and cultural elements (man and nature influence and shape each other). The geographical region is thus conceived as a concrete, tangible entity, a physical reality that exists as a reference framework for the population living there (Contel, 2015). The task of a geographer is to explore and discover 
the combination of factors responsible for such "regional configuration". After the Second World War, the region and regionalization are being studied in the context of the formation of an urban network. Knowledge of the urban network led directly to the geographical understanding of regional reality.

Most often, the region is defined as a complex spatial unit. Its structure differs from the environment. Regions are a concrete reality. They are developing and constantly increasing cohesion. They can suddenly disappear, due to the action of an external agent or slow decomposition of the system. Many factors influence the formation and development of the region. Natural factors such as relief, climate, soil can limit development, or they have the role of a catalyst. Historical factors are also of importance, i.e. all elements that constitute the collective identity of a single spatial entity. Traffic is an important factor for the formation and development of the region. The competence of public administration at the regional level, as well as the ability to control political decisions at that level, is also essential for maintaining the region's internal coherence.

The region can be formed by internal generator from a regional center. In this case, the condition of the region's creation is polarization, that is, the existence of a larger urban center, which with its influence shapes the environment. The region can also be the result of an external division and delimitation. Regional shaping is reflected in important spatial determinants such as position, connection, size, possubility, centers, etc. Spatial components of regional identity have their qualitative and quantitative aspects (Кнежевић, 2003). At the end of the 20th century, the region became more economical, more political, as well as supranational. Progress in the area of transport and communication as well as the global economy has caused a crisis of the classic concept of the region. In contemporary conditions, the region is no longer a living reality that has its own internal coherence. Due to spatial and temporal compression of the global era, the regions lost the historical stability.

Globalization has a strong impact on the political, economic, and cultural processes in the world. In political and economic terms, it leads to the opening of national markets, and in a cultural sense - the adaptation of national cultural patterns to the western culture. Since the mid-1980s, the analysis of political, economic, and cultural processes has become increasingly important among geographers, which is confirmed by the fact that scientific circles are increasingly writing about it (Newman and Kliot, 1999; Miloradovic, 1999; Trkulja, 2003; Soros, 2002; Stiglitz, 2003; Sen, 2003; Milovanović, 2003). Acceptance of elements of the social sciences in modern regional research aims to overcome the limitations of traditional regional geography. Numerous authors from the 
1980s and early 1990s in their works explicitly point to a turning point in regional research (Gilbert, 1988; Lee, 1985; Murphy, 1991; 2006; Paasi, 1986; Pred, 1984; Sayer, 1989; Thrift and Pred, 1981; Thrift, 1990; 1991; 1993; 1994).

Due to increasingly complex international relations, the geographical idea of the world as a mosaic of static spatial units is unrealistic. The world is not structured in such a neat way, but on the contrary, regions disappear and reappear and are being transformed under the influence of various economic, political and cultural factors (Levis and Wigen, 1997). It is precisely for this reason that there is a need to redefine the relationship between the global regional - national (Ristic, 2012; Ristic and Marinkovic, 2014). Under the influence of regional science and new economic geography, the traditional concept of the region as homogeneous spatial units is abandoned. Regarding traditional regional geography, where the regions are defined as separate entities, on the basis of internal integrity, contemporary regional geographers consider the region as an entity created through social interaction (Vresk, 1997).

Regions are often studied as a product of the interaction of individuals or social groups in different economic, political, and cultural contexts. Three different approaches in contemporary regional geography can be distinguished: the region as a local response to contemporary economic processes in the world, the region as a medium for social interaction, harmonization of people, nature, and social relations in a certain time and space, as well as the region as a center / identification (Gilbert, 1988). The first approach examines the region as a spatial organization of social processes and production (circulation of capital in social processes) with an emphasis on objective reality, on the political and economic basis of the region and the role of economic factors in space design. By the second approach, the region is a subject of social interaction. Territory as well as time, and material basis (nature, economy) is accepted as social and cultural constructions. The third approach accentuates the culture of the region, concentrating on problems such as regional identification and regional identity. A region is considered as a set of cultural relations of a particular social group and a certain place or territory. Although they include different assumptions, all three approaches that define regional specificity have similarities that are contrary to traditional regional geographic units. While emphasizing different factors in space design, the three approaches are complementary in explaining the social structure of space.

Although most geographers consider the regions to be social constructions, they are still not clearly defined in practice (Allen et al., 1998; Paasi, 2010). Regions are not isolated islands, but their development is influenced 
by political, economic and cultural processes beyond their borders (Paasi, 1986; 2002a; 2002b; 2009a; 2009b; 2010; 2011). The region is not a closed system, and it is not immune to external influences. Also, each region is open to challenges from inside and outside. The regions have vague and more or less clear boundaries, but also a symbolic form that manifests in a social practice that produces or reproduces a region that defines a regional identity. Geographical knowledge of the regions can contribute to a better understanding of economic, political and cultural changes in the world. Thinking through the prism of regional geography is crucial to solving spatial problems in the world. Understanding the influence of structures, relationships and relationships in space on these problems contributes to solving them (de Blij, 2005).

The new concept defines the region through social interaction and has different approaches, from political and economic, through geographical, to culture, but it is common for all of them to view the region as the result of interactions between individuals, groups and institutions. This process creates an internal homogenized space and determines identity. Accordingly, the regions are models that indicate that different factors act and create a recognizable geographical landscape. In the global age, the main research problems of contemporary regional geography remain the regions, the organization of geographical space, regional development and regional identity, as a reflection of complex linkages on the relation between nature and society. Contemporary regional geography aims to inform the scientific and professional public with the pluralistic nature of the world and new trends that link the global level and levels of regional and local communities (Вујадиновић et al., 2015). Regions according to the conception of contemporary regional geography represent analytical tools in geographical, economic, political, historical and sociological research (Claval, 2007). Although some of the contemporary theoretical discourses point to the end of the "region", and globalization attempts to homogenize space, however fragmentation and regionalization in the world continue.

\section{Results and discussion}

\section{Region and territorial capital}

In the context of the region and regional development, territorial capital gets more and more important. The territorial capital refers to the total development potential of a region, i.e. on its material and intangible elements (Storper, 1997). Different elements of the region can be included in 
the analysis of territorial capital, from strategic position and size, through human resources, to cultural heritage. The importance of these elements is reflected in the fact that they can significantly affect the competitiveness of the region. However, European experience has shown that these elements are often limiting factors of development, which significantly impedes the competitiveness of the region. The territorial capital of the region is a complex term and encompasses human, economic, cultural, environmental, and social capital. The availability of development resources (natural, material, knowledge, skills, information and technology) largely determines the development of the region. Elements of territorial capital are interconnected and conditioned. So, for example, environmental problems can diminish or completely offset the attractiveness of certain regions in terms of tourism development, healthy food production and housing, while the unfavorable educational structure of the population can disable investment in the region. The synthesis of different types of capital that a region can possess in comparison with others determines its competitiveness (Вујошевић et al., 2010).

Territorial competitiveness of the region does not only refer to economic competitiveness (the region's ability to connect with the national and international market, i.e. to participate equally in the market "competition"), but also include social, cultural and other aspects (Јанковић, 2007). Depending on the volume and quality of different forms of capital, the comparative advantage of the region is reflected in the attractiveness and possibilities of job creation, investments in infrastructure construction, entrepreneurship and investments in small and medium enterprises, the attractiveness of the environment as a place of residence and recreation. Increasing territorial competitiveness is an evolutionary process that involves monitoring market changes, respecting local specifics, involving stakeholders and institutions, and integrating and coordinating among sectors in order to optimally exploit and achieve sustainable integrated development. European experiences have shown that regions with natural resources, a qualified human potential and an institutional system that fosters innovative business activities are attractive for development. Isolated regions without high quality natural and qualified human resources have no conditions to engage in development flows. Social capital plays an important role in the region. Social capital includes the specificities of the region, social norms, trust, quality, and frequency of interactions, cooperation and common interest, recognizable identity, transparency of decisions and actions, etc. The population living on the same territory shares the same or similar experiences and belongs to the same region. Social capital is a resource that creates and maintains interpersonal relation- 
ships, connects and directs people towards a common goal (Shucksmith, 2000). The role of social capital is high, especially in the creation of economic capital. An example of this connection is different regional associations. They represent the interests of their members gathered around common interests (Јанковић, 2007). Within such associations there can be the strengthening of social capital in the institution, association through education, informing and connecting different actors. Social capital is an essential element of human interaction and network of relationships. Personal contacts with important economic actors in the country and abroad in European practice have proven to be an important factor in the revival of the region. A significant factor in the development of the region is the establishment and strengthening of social cohesion. It is achieved by the participation of the population, i.e. by establishing a positive interactive approach in which the population is motivated to participate in resolving regional problems, and the regional government is ready and able to meet the needs of the population whenever possible.

European experiences show that regional initiatives through partnerships of various actors in the planning, implementation, financing of development projects contribute to the improvement of social capital and the efficiency of regional development projects (Јанковић, 2007). Social capital can initiate social change, but it can be limited by inherited and newly created conflicts and poor integration of the population. Knowledge and experience of the population are necessary in the realization of development and investment programs so that the projects would not be unrealistic. However, in the conditions of over-interference of the state, regional as well as local initiatives is often impeded or absent, and the population, relying entirely on state interventions, becomes uninterested and inert. The identity of regional and local communities, recognizability and comparative advantage can influence the strengthening of mutual trust and cooperation among the population, as opposed to mistrust due to poor experiences and social isolation. The degree of functional integration is more significant if there is a greater connection between the inhabitants and the environment, and if there is a desire to stay in place. Economic underdevelopment, depopulation and traffic isolation of certain regions often lead to social exclusion of the population. Experience from Europe has shown that it is particularly pronounced in some mountain regions, which are significantly lagging behind in economic, cultural, educational and infrastructural terms compared to other regions. The scientific and professional public, the creators of economic policy and institutions, give more attention to the areas outside the large city centers. In order to successfully implement economic policies (i.e. Territorial cohesion 
policy), the concept of territorial capital precisely applies to these territories. The modern approach to the territorial capital in the member states of the European Union is important for understanding and defining the future regional development of Serbia, primarily because regional differences in Serbia are higher than any member of this organization.

\section{Regionalization - an instrument of decentralization}

Regionalization is an instrument that can achieve the best possible use of space. It is an instrument of the creation of a region - spatial units within one state and the way of conducting state policy aimed at reducing regional disproportions and structural adjustment of the region to existing regional resources. According to Borgegard et al. (1995), regionalization can be defined as an instrument for balancing demographic processes in a country in which there is a demographic disparity (large differences in population concentration on the one hand and dispersion on the other), as well as the level of authority that fills the space between central and local authorities through regional populations politics.

Regionalization establishes the regions as administrative and political units within the national state. Consequently, regionalization implies decentralization, as it transfers the part of the authorities from the national to the regional level. The forms of the regional structure depend on the historical, geographical, political, and cultural specifics of the space. Regions can be formed on the basis of:

- characteristic geographical, cultural, socioeconomic or ethnic characteristics,

- political criteria by agreement of political actors, and

- administrative criteria (structure, population, GDP, etc.).

Decentralization implies the existence of a network of different levels of local government. Each self-government has certain characteristics and a circle of jurisdiction. Strengthening of local government means financial autonomy and the use of its own potentials primarily in the sphere of fostering economic development, but also the development of a local government network. In different countries, this network has different forms, and most often there are three levels within the network of local authorities: municipalities, districts, and regions. In the European Union, increasing attention is paid to the principle of subsidiarity, when it comes to relations between existing levels of government. According to this principle, the advantage in carrying out certain jobs is that the level of government that is closest to the citizens (the principle of democracy). If that level of government is unable to 
carry out entrusted tasks, due to staff, organizational or other reasons, they are transferred to a higher level (down-to-top). Thus, the work is carried out by the level of government that can best implement it (the principle of economy and rationality in the use of public funds).

The region represents the highest level of organization of self-government. His presence signifies the existence of a three-step organization of local government. Regions are territories that are specific and recognizable in physical, geographical, historical and socioeconomic terms, so that citizens are identified with them. The region is a link between local communities and the state. The regional level of government brings together jobs at the local and national level. Regions represent almost optimally rounded spatial unit characterized by economic, geographic and traffic characteristics, interconnection of parts of the region and approximate conditions for independent existence and development (Јовичић, 1993). It is a unit large enough to organize different forms of social life in its framework, and politically it can be strong enough with a large number of citizens / voters, so that it is a kind of counterbalancing to the central government, without jeopardizing the territorial integrity of the state. Although it would be more realistic and effective to look at the contemporary region as a spatial form of political organization, many geographers are still prone to naturalizing the idea of a region.

Regionalization is primarily on the function of social and economic development and does not pose a threat to national integrity. On the contrary, through the region as a cohesive element, it contributes to decentralization, balanced economic development, the democratization of society, and the political stability. Regionalization assumes the rationalization of the administrative apparatus, in order to achieve its greatest political and economic efficiency and bring the local decision-making site closure. Decentralization and application of the principle of subsidiarity ensure greater participation of citizens in political decision - making, resulting in a higher degree of democracy, as well as greater legitimacy of political decisions.

Regions and regionalization can contribute to achieving goals such as:

- more democracy,

- balanced development at the national level,

- the creation of a regional level of government as an administrative link between central and local authorities,

- Creating conditions for spatial planning and economic development,

- directing urbanization, 
- redistribution of gross national income,

- establishing a balance between the quality of agricultural and industrial production,

- establishing a systemic institutional balance,

- affirmation of regional specificities,

- preserving the traditional and cultural values of the region,

- achieving greater competition between the region, and

- more transparency and accountability

\section{Conclusion}

From the aspect of the region, regionalization contributes to its affirmation and preservation of regional specifics, primarily cultural, but also of interest - social, economic, political, etc. From the aspect of the state as a superior entity, regionalization contributes to the achievement of a balanced development of the region and more efficient connection of state authorities to the local one. These two aspects of regionalization should be compatible, but in practice this does not usually come about.

In addition to creating a new level of government in the state territorial organization, regionalization leads to the formation of new institutions that can vary widely in terms of accountability and power. These institutions are always placed above the level of local institutions. Regionalization introduces a completely new type of relationship between different levels of government within the state (redistribution of economic, legislative, executive, financial and other powers). Establishing the regional level of government in the political system of the state is a complex functional process of building a complex structure of society with different levels of decision-making. Regionalization must not be jeopardized by the local level of government, but should be a guarantee for the autonomy of local and regional institutions and entities.

Considering the role of regionalization in the economic and political processes in the European Union, its institutional and legal framework has been established. The process of institutionalized regionalization began in the West European countries in the 1950s, especially to intensify in the 1980s, when the European Union accepted the idea of European regions. Then begins the revival of the region in countries like France and Italy. Countries where the region has not traditionally existed, they themselves began to define regions of 
different names and functions. The common vision of all regions is economic development and prosperity. Europe encourages the process of regional formation - regionalization, in order to better integrate the population and encourage development. Special attention is paid to the so-called European regions that cover parts of the territory of two or more states, and are often formed in border areas. These regions are created by spontaneous organization and initiatives of local communities, which, through the creation of common regional policies and attracting investments, solve the problems of their residents (new jobs, etc.). Hence, it is not surprising that a great deal of attention is paid to the implementation of regional programs in developed European countries and, consequently, allocates a significant part of the budget.

As one of its main objectives, the European Union has set the reduction of the existing differences between the regions in the member states by establishing a common policy of regional development and interregional cooperation (Komšić, 2007; Mirić, 2009). By establishing a regional authority structure in EU member states and decentralizing state functions, more favorable conditions have been created to make regional development potentials more efficient. The concept of regionalization is primarily based on economic motives, while political motives mainly concern the protection of the right to linguistic and cultural identity of the ethnic communities of separate regional identities. In a European context, regionalization can also be seen as a form of transnational integration and cooperation between European countries.

\section{Acknowledgements}

The paper is the result of the research within the project no. 176008 funded by the Ministry of Education and Science of the Republic of Serbia.

\section{References}

Allen, J., Massey, D. and Cochrane, A. (1998). Rethinking the Region. London: Routledge.

Amin, A. (2004). Regions Unbound: Towards a New Politics of Place. Geografiska Annaler. Series B, Human Geography 86 (1): 33-44.

Bristow, G. (2010). Critical Reflections on Regional Competitiveness. London: Routledge.

Castells, M. (1996). The Rise of the Network Society. Vol. I. The Information Age: Economy, Society, and Culture. Oxford: Blackwell. 
Claval, P. (2007). Regional Geography: Past and Present (A Review of Ideas, Approaches and Goals). Geographia Polonica, 80 (1): 25-43.

Contel, F. B. (2015). Concepts of region and regionalization: Aspects of its evolution and possible uses to health regionalization. Sauce Soc., 24 (2): 447-459.

Cooke, P. and Morgan, K. (1994). Growth Regions Under Duress: Renewal Strategies in Baden Wurttenberg and Emilia Romagna. In Amin, A., Thrift, N. eds.. Globalization, institutions, and regional development. Oxford: Oxford University Press, 91-117.

De Blij, H. J. (2005). Raising Geography's Profile in Public Debate. Progress in Human Geography 29 (2): 167-173.

Gilbert, A. (1988). The New Regional Geography in English and Frenchspeaking Countries. Progress in Human Geography 12: 208-228.

Keating, M. (1998). Political economy of regionalism. In: Keating, M., Loughlin, J. (Eds.), 17-41.

Komšić, J. (2007). Principi evropskog regionalizma - Principles of European Regionalism, „PHILIA”, Novi Sad.

Levis, M. and Wigen, K. (1997). The Myth of Continents: A Critique of Metageography. Berkeley: University of California Press.

Lee, R. (1985). The Future of the Region: Regional Geography as Education for Transformation. In Geographical Futures Ed. R King, Sheffield: Geographical Association, 77-91.

MacLeod, G. (2001). New Regionalism Reconsidered: Globalization and the Remaking Of Political Economic Space. International Journal of Urban and Regional Research 25 (4): 804-829.

Meijers, E., and Romein, A. (2003). Realizing Potential: Building Regional Organizing Capacity in Polycentric Urban Regions. European Urban and Regional Studies 10 (2): 173-186.

Milovanović, S. (2003). Internet i globalizacija. Aspekti globalizacije sa pregledom osnovnih pojmova, Beograd: Dosije.

Miloradović, A. (1999). Globalizacija. Osijek-Zagreb-Split: Pan Liber.

Mirić, O. (2009). Regionalna politika Evropske unije kao motor ekonomskog razvoja. Evropski pokret u Srbiji, Beograd.

Murphy, A. (1991). Regions as Social Constructs: the Gap between Theory and Practice. Progress in Human Geography 15 (1): 22-35. 
Murphy, A. (2006). Enhancing Geography's Role in Public Debate. Annals of the Association of American Geographers 96 (1): 1-13.

Newman, D. and Kliot, N. (1999). Globalization and the Changing World Political Map. Geopolitics 4 (1): 1-16.

Paasi, A. (1986). The Institutionalization of Regions: a Theoretical Framework for Understanding the Emergence of Regions and the Constitution of Regional Identity. Fennia 164: 105-146.

Paasi, A. (2002a). Place and Region: Regional Worlds and Words. Progress in Human Geography 28 (6): 802-811.

Paasi, A. (2002b). Regional Transformation in the European Context: Notes on Regions, Boundaries and Identity. Space and Polity 6 (2): 197-201.

Paasi, A. (2009a). The Resurgence of the Region and Regional Identity: Theoretical Perspectives and Empirical Observations on the Regional Dynamics in Europe. Review of International Studies 35 (S1): 121-146.

Paasi, A. (2009b). Regions and Regional Dynamics. In Rumford, C (Ed). The SAGE Handbook of European Studies, Sage, London, 464-484.

Paasi, A. (2010). Regions are Social Constructs, But Who or What Constructs Them? Agency in question. Environment and Planning A 42 (10): 2296-2301.

Paasi, A. (2011). The Region, Identity, and Power. In: Procedia Social and Behavioral Sciences, 14: 9-16.

Pred, A. (1984). Place as a Historically Contingent Process. Annals of the Association of American Geographers, 74 (2): 279-297.

Ristić, D. (2012). Diskurzivni karakter regionalnog identiteta, u: Regioni $i$ regionalizacija - sociološki aspekti, Priredili Valentina Sokolovska i Dušan Marinković, Novi Sad: Mediterran Publishing 93.116.

Ristić, D., Marinković, D. (2014). Društvena konstrukcija regiona: teritorija, mesto, identitet. In: V. Sokolovska i Ž. Lazar (Eds.). Regioni i regionalizacija 3: 73-89.

Sayer, A. (1989).The New Regional Geography and Problems of Narrative. Environment and Planning D: Society and Space 7 (3): 253-276.

Sen, A. (2002). Razvoj kao sloboda. Beograd: Filip Višnjić.

Shucksmith, M. (2000). Endogenous Development, Social Capital and Social Inclusion: Perspectives from LEADER in the UK. Sociologia Ruralis, 40 (2): 208-218.

Stiglitz, J. E. (2003). Globalization and Its Discontents. London: W.W. Norton,. 
Storper, M. (1997). Territories, Flows, and Hierachies in Global Economy, In: Cox, K. (Ed.). Spaces of Globalization: Reasserting the Power of the Local, The Guilford Press, 19-44.

Soros, G. (2002). On Globalization. Oxford: Public Affairs Ltd.

Trkulja, J. (2003). Globalizacija kao potčinjavanje ili šansa. U: Pavićević, V. i dr. (ur.) Aspekti globalizacije sa pregledom osnovnih pojmova, Beograd: Dosije.

Thrift, N. and Pred, A. (1981). Time-geography: a New Beginning. Progress in Human Geography, 5 (2): 277-286.

Thrift, N. (1990). For a New Regional Geography 1. Progress in Human Geography 14 (2): 272-279.

Thrift, N. (1991). For a New Regional Geography 2 Progress in Human Geography 15 (4): 456-565.

Thrift, N. (1993). For a New Regional Geography 3. Progress in Human Geography 17: 92-100.

Thrift, N. (1994). Taking Aim at the Heart of the Region. In D. Gregory, R. Martin, and G. Smith, eds. Human Geography: Society, Space and Social Science. University of Minnesota Press, Minneapolis, 200-231.

Vresk, M. (1997). Regionalna geografija danas. Acta Geographica Croatica 32: 69-82.

Вујадиновић, С., Павловић, М. и Шабић, Д. (2015). Проблеми и изазови савремене регионалне географије. У Станковић, С., Филиповић, Д. и Ђурђић, С. (ур.): Достигнућа, актуелности и изазови географоке науке и праксе, 4. Српски конгрес географа, Географски факултет у Београду, Српско географско друштво, Београд, 1: 289-297.

Вујошевић, М., Зековић, С. и Маричић, Т. (2010). Постсоцијалистичка транзиција у Србији и територијални капитал Србије - стање, неки будући изгледи и предвидљиви сценарији. Београд: Институт за архитектуру и урбанизам Србије, 39-47.

Јанковић, Д. (2007): Значај социјалног капитала у развоју локалних сеоских заједница. Зборник Матице српске за друштвене науке, 123: 173-190.

Јовичић, М. (1993). Лексикон политичке културе. Савремена администрација, Београд.

Кнежевић, М. (2003). Региони, држава, регионализам, у: Зборник радова: Култура у процесима развоја, регионализације и евроинтеграције Балкана, Филозофски факултет - Универзитет у Нишу - Институт за социологију, Ниш, 125-144. 